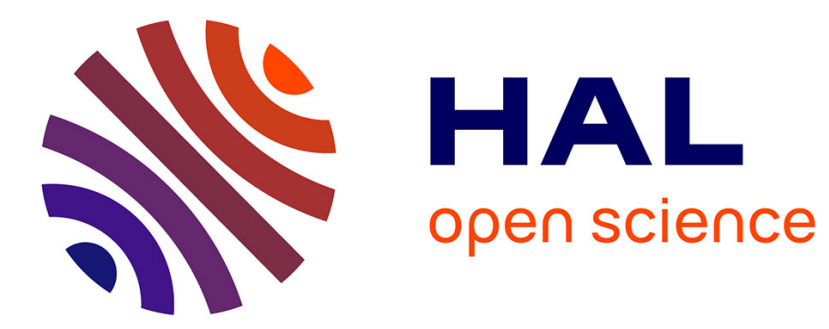

\title{
Zygomatic swing approach to the infratemporal fossa
}

\author{
M. Schlund, A. Depeyre, G. Raoul, R. Nicot
}

\section{To cite this version:}

M. Schlund, A. Depeyre, G. Raoul, R. Nicot. Zygomatic swing approach to the infratemporal fossa. British Journal of Oral and Maxillofacial Surgery, 2019, 57, pp.600 - 602. 10.1016/j.bjoms.2019.04.014 . hal-03488154

\section{HAL Id: hal-03488154 \\ https://hal.science/hal-03488154}

Submitted on 20 Dec 2021

HAL is a multi-disciplinary open access archive for the deposit and dissemination of scientific research documents, whether they are published or not. The documents may come from teaching and research institutions in France or abroad, or from public or private research centers.
L'archive ouverte pluridisciplinaire HAL, est destinée au dépôt et à la diffusion de documents scientifiques de niveau recherche, publiés ou non, émanant des établissements d'enseignement et de recherche français ou étrangers, des laboratoires publics ou privés.

\section{다)(1) $(5$}

Distributed under a Creative Commons Attribution - NonCommerciall 4.0 International 


\section{Zygomatic swing approach to the infratemporal fossa}

Matthias Schlund, Arnaud Depeyre, Gwénaël Raoul, Romain Nicot

Matthias Schlund, MD, Chef de Clinique des Universités - Assistant Hospitalier

-Univ. Lille, Oral and Maxillofacial Surgery Department, CHU Lille, F-59000 Lille, France;

INSERM U 1008, Controlled Drug Delivery Systems and Biomaterials, F-59000 Lille, France

Arnaud Depeyre, MD, MSc, Praticien Hospitalier

-Univ. d'Auvergne, Oral and Maxillofacial Surgery Department, Estaing Hospital, CHU Clermont-Ferrand, F-63000 Clermont-Ferrand, France

-INSERM U 1008, Controlled Drug Delivery Systems and Biomaterials, 59000 Lille, France

Gwénaël Raoul, MD, PhD, Professeur des Universités - Praticien Hospitalier

-Univ. Lille, Oral and Maxillofacial Surgery Department, CHU Lille, F-59000 Lille, France;

INSERM U 1008, Controlled Drug Delivery Systems and Biomaterials, F-59000 Lille, France

Romain Nicot, MD, MSc, Maître de Conférence des Universités - Praticien Hospitalier -Univ. Lille, Oral and Maxillofacial Surgery Department, CHU Lille, F-59000 Lille, France

Corresponding author :

Matthias Schlund

Service de Chirurgie Maxillo-Faciale et Stomatologie

Hôpital Roger Salengro

Rue Emile Laine

59037-Lille-Cedex

France

Tel : +33320443676

Fax : +33320445860

e-mail : matthias.schlund@chru-lille.fr 


\section{Zygomatic swing approach to the infratemporal fossa}

Keywords: zygomatic swing; infratemporal fossa; pterygopalatine fossa; cancer surgery

Infratemporal and pterygopalatine fossas are difficult to access surgically, and numerous approaches have been described and sometimes combined. ${ }^{1}$ To the best of our knowledge, maxillary swing was first described by Hernández Altemir in $1986^{2}$ as an alternative access to infratemporal tumours. It opens the maxillozygomatic complex like a book (in a similar way to the mandibular swing technique), which leaves it vascularised through the facial skin that had been left attached, and it leads to good open visualisation and access of the infratemporal fossa. Morbidity is low compared with other approaches (hearing deficiency and facial palsy in lateral approaches, and facial palsy and issues with mastication in transmandibular inferior approaches). Endoscopy is another alternative for removal, although it is limited to medial tumours and en bloc resection is impossible.

We present a technique of modified zygomatic swing that does not involve the hard palate, and describe its use in the removal of a malignant tumour of the infratemporal fossa in an 18year-old woman who had no available medical history.

\section{Surgical technique}

First, we made a Weber-Ferguson skin incision, and carried the dissection as far as the underlying bone, although we had to be careful to limit the subperiosteal cut. It was necessary to expose enough bone to complete the osteotomies with a piezoelectric saw (Fig.1) but not so much that the zygoma could be devascularised. The medial osteotomy was cut medially to the canine pillar, and the lower osteotomy above the dental roots as far as the first molar. We 
started the upper osteotomy on the medial part of the orbital rim, laterally to the lacrimal drainage system, and continued it on the anterior part of the orbital floor just behind the orbital rim, as far as the basal part of the frontal process of the zygoma. We completed the lateral osteotomy on the temporal surface of the zygomatic bone to link the upper and lower cuts.

When the osteotomies had been completed, we mobilised the zygoma like an open book, (Fig. 2) and made a guided fracture of the zygomatic arch. The zygoma was vascularised by the anterior periosteum, which was left attached and allowed direct visualisation of the posterior wall of the maxillary sinus, orbital floor, and infratemporal fossa. We excised the tumour with safe margins as a result of the improved visibility.

The excision included the orbital floor, the posterior wall of the sinus, the alveolar part of the maxilla from the second premolar, the hard palate on the same side, and the pterygoid process. Histological evaluation later confirmed the complete removal of a malignant tumour of the peripheral nerve sheath.

After the tumour had been excised, we put the zygoma back in place and reconstructed the orbital floor using a bicortical parietal bone graft. We fixed titanium miniplates medially on the orbital rim and laterally on the frontal process of the zygoma (Fig. 3), and attached the orbital floor graft to the orbital rim with a titanium miniplate.

\section{Conclusion}

Zygomatic swing, by opening the middle third of the face, allows wide access to the infratemporal fossa and, therefore, safe removal of a lesion. Morbidity is low because the 
zygoma is then fixed back into its original position, and aesthetic complications are avoided. ${ }^{3}$ The zygoma is not a mobile bone, which limits pain postoperatively. ${ }^{4}$ The technique is safe because vascularisation is preserved, unlike that in grafting techniques involving translocated facial bone..$^{5}$

\section{Conflict of interest}

We have no conflicts of interest.

\section{Ethics statement/confirmation of patient's permission}

No ethics approval was needed as a waiver of ethics approval was obtained. The patient's consent was obtained.

\section{References}

1 Tiwari R, Quak J, Egeler S et al. Tumors of the infratemporal fossa. Skull Base Surg 2000;10:1-9.

2 Hernández Altemir F. Transfacial access to the retromaxillary area. J Maxillofac Surg 1986;14:165-70.

3 Chan JY, Tsang RK, Wei WI. Morbidities after maxillary swing nasopharyngectomy for recurrent nasopharyngeal carcinoma. Head Neck 2015;37:487-92.

4 Otremba M, Adam S, Omay SB, et al. Maxillary swing approach for extended infratemporal fossa tumors. Laryngoscope 2013;123:1607-11.

5 Hao SP. Facial translocation approach to the skull base: the viability of translocated facial bone graft. Otolaryngol Head Neck Surg 2001;124:292-6.

\section{Figure legends}


Fig. 1. Drawing of the technique. The cut bone is shown in purple, straight lines represent the piezoelectric osteotomy, and the rugged line is where the guided fracture was made.

Fig. 2. Peroperative photograph showing the mobilised zygoma, the osteotomies, and the tumour on the posterior wall of the maxillary sinus.

Fig. 3. Peroperative photograph showing the fixation of the zygoma on the orbital rim on the superior part of the frontal process of the zygoma and the fixation of the parietal plate to reconstruct the floor of the orbit. 


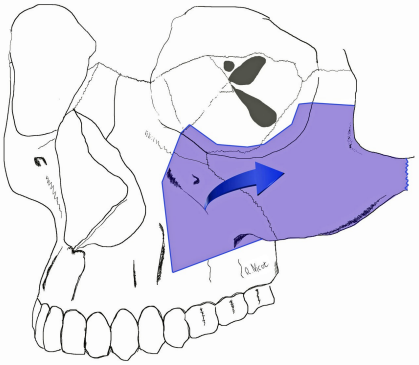




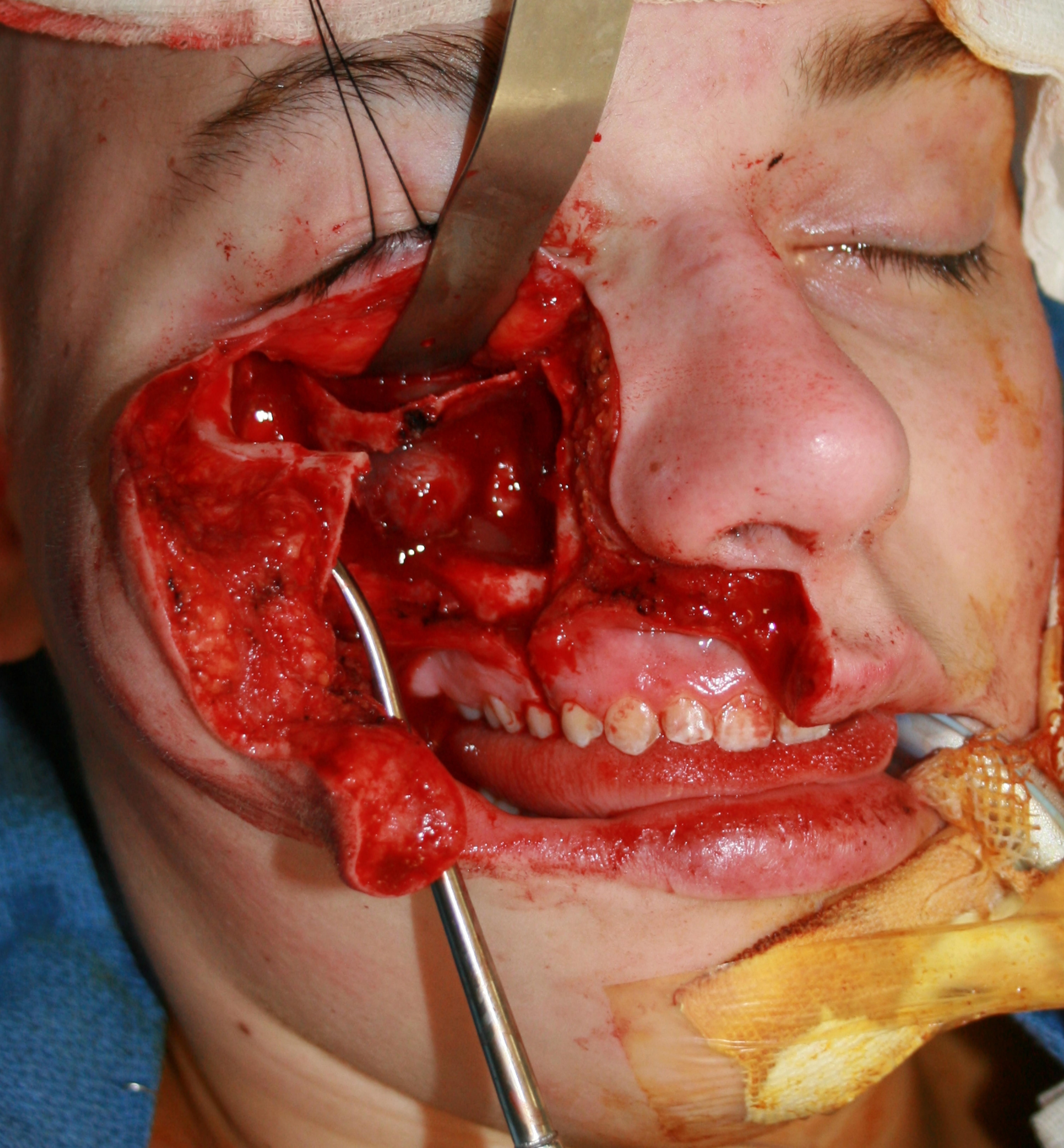




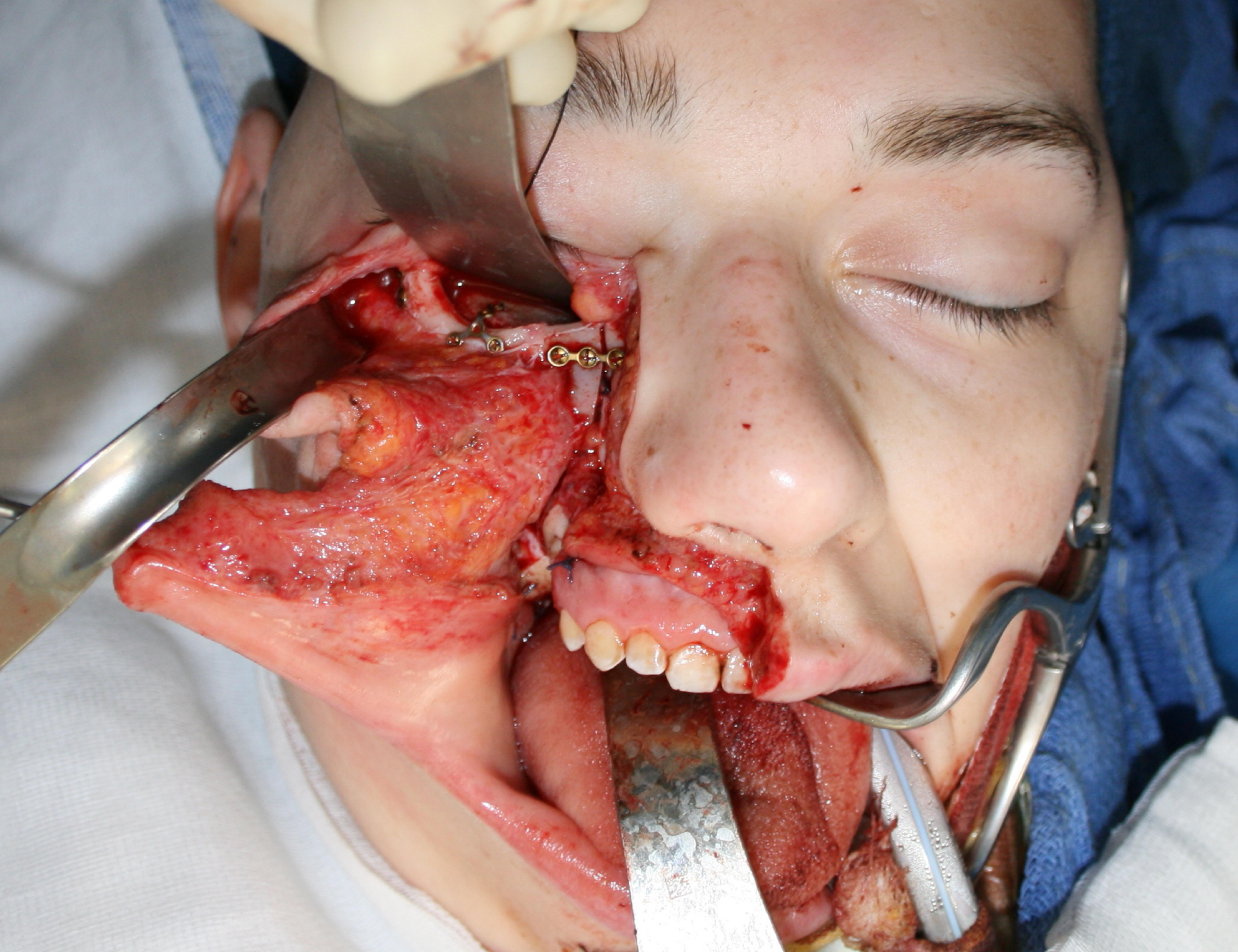

